

Available online at AL-KAUNIYAH: Jurnal Biologi

Website: http://journal.uinjkt.ac.id/index.php/kauniyah

AL-KAUNIYAH: Jurnal Biologi, 12(2), 2019, 207-219

\title{
EFEK KONSUMSI KERANG BULU (Anadara antiquata) TERHADAP KUANTITAS DAN KUALITAS SPERMATOZOA Mus musculus L.
}

\author{
EFFECT OF SHELLFISH (Anadara antiquata) CONSUMPTION ON \\ QUANTITY AND QUALITY OF MUS musculus SPERM
}

\author{
Neny Safitri, Evi Hanizar \\ Prodi Pendidikan Biologi, FPMIPA IKIP PGRI Jember, Jl. Jawa 10) Jember, Jawa Timur, Indonesia \\ *Corresponding author: evihanizar@gmail.com
}

Naskah Diterima: 10 Juli 2019; Direvisi: 18 September 2019; Disetujui: 24 Oktober 2019

\begin{abstract}
Abstrak
Kerang bulu (Anadara antiquata) merupakan salah satu makanan yang mengandung nutrisi tinggi, seperti protein, lemak, vitamin, dan mineral, yang berpotensi memperbaiki serta meningkatkan kualitas spermatozoa. Penelitian ini bertujuan untuk menganalisis efek A. antiquata terhadap kuantitas dan kualitas spermatozoa Mus musculus. Penelitian ini merupakan penelitian eksperimental murni dengan rancangan acak lengkap pola faktorial. Faktor pertama adalah kondisi kerang, yakni mentah dan kukus, dan faktor kedua adalah konsentrasi $0 \mathrm{~g} / \mathrm{mL}, 75 \mathrm{~g} / 100 \mathrm{~mL}$, dan $100 \mathrm{~g} / 100 \mathrm{~mL}$. M. musculus yang digunakan sebanyak 25 ekor, terdiri dari lima perlakuan dengan masing-masing lima kali ulangan. Parameter yang diamati adalah konsentrasi (kuantitas), motilitas, dan morfologi (kualitas) spermatozoa. Data dianalisis menggunakan uji Kruskal-Wallis dan uji lanjut Duncan. Hasil penelitian menunjukkan bahwa A. antiquata berpengaruh nyata terhadap konsentrasi dan motilitas spermatozoa, sedangkan morfologi tidak memberikan pengaruh yang nyata. Kondisi kerang mentah dengan konsentrasi $100 \mathrm{~g} / 100 \mathrm{~mL}$ memberikan efek rata-rata terendah terhadap konsentrasi dan motilitas spermatozoa, sementara kerang kukus dengan konsentrasi $75 \mathrm{~g} / 100 \mathrm{~mL}$ meningkatkan rata-rata konsentrasi dan motilitas spermatozoa tertinggi. Penelitian ini memberi kesimpulan bahwa mengonsumsi kerang kukus lebih baik untuk meningkatkan konsentrasi dan motilitas spermatozoa, dibandingkan dalam kondisi mentah. Peningkatan dosis kerang kukus tidak linier terhadap respon kuantitas dan kualitas spermatozoa.
\end{abstract}

Kata kunci: Anadara antiquata; Konsentrasi spermatozoa; Motilitas; Morfologi; Mus musculus

\begin{abstract}
Shellish (Anadara antiquata) was one of the foods that contained high nutrients such as protein, fat, vitamins, and minerals that had the potential to improve and increase the quality of sperm. The study aims to analyze the effect of the shellfish on the quantity and quality of Mus musculus sperm. This study was a purely experimental study with a completely randomized factorial pattern; the first factor was the condition of shellfish which was raw and steamed, and the second factor was concentrations of $0 \mathrm{~g} / \mathrm{mL}, 75 \mathrm{~g} / 100 \mathrm{~mL}$ and $100 \mathrm{~g} / 100 \mathrm{~mL}$. Twenty five individuals of $M$. musculus were subject to five treatments, each with five replications. Parameters observed were concentration, motility, and morphology of sperm. Data were analyzed using the Kruskal-Wallis test and Duncan's advanced test. The results showed that shellfish had a significant effect on the concentration and motility of sperm, whereas there was no significant effect on morphology. The dose which gave the effect was $100 \mathrm{~g} / 100 \mathrm{~mL}$ of raw shellfish and $75 \mathrm{~g} / 100 \mathrm{~mL}$ of steamed shellfish. This study concluded that consuming steamed shellfish was better than raw for increasing the concentration and motility of sperm. The shellfish dose increased is not linear in response to the quantity and quality of sperm.
\end{abstract}

Keywords: Anadara antiquata; Concentration of sperm; Motility; Morphology; M. musculus

Permalink/DOI: http://dx.doi.org/10.15408/kauniyah.v12i2.11794 


\section{PENDAHULUAN}

Masalah infertilitas masih menjadi persoalan bagi pasangan yang ingin mendapatkan keturunan, namun fokus masalah sering ditujukan pada pihak istri. Faktanya adalah sebagian infertilitas disebabkan oleh pihak istri dan sebagian oleh suami. Infertilitas merupakan ketidakmampuan pasangan untuk menghasilkan keturunan, setelah melewati periode minimal satu tahun dan melakukan intercourse secara rutin tanpa menggunakan pelindung (Hochschild, 2009). Beberapa indikator digunakan untuk menilai infertilitas baik pada pria maupun wanita, khusus infertilitas pria dilihat dari abnormalitas berbagai kondisi semen, seperti volume, $\mathrm{pH}$, viskositas, kuantitas, dan kualitas spermatozoa (Ferial \& Suryani, 2011). Kondisi tersebut karena beberapa faktor, mulai dari gaya hidup, pola makan atau kebiasaan diet, dan usia (Styne, 2003; Hosomi, Yoshida, \& Fukunaga, 2012) hingga genetik, khususnya gen-gen yang terdapat pada daerah AZF dalam lengan panjang kromosom Y (Hanizar, 2004; Hopps et al., 2003).

Selain usia dan genetik, tiga faktor lainnya dapat diubah untuk memperbaiki infertilitas pria, yaitu dengan mengatur makanan yang mengandung nutrisi makro maupun mikro. Salah satu makanan yang mengandung gizi tinggi adalah kerang, yang ditunjukkan dari hasil kajian nutrisi yang terkandung di dalamnya. Sebuah penelitian memaparkan, protein, lemak, dan karbohidrat yang terdapat di dalam kerang darah (Anadara granosa), masing-masing sebesar $11,84 \%$, $0,6 \%$, dan 3,75\% (Daluningrum, 2009). Sementara jenis lain, kerang bulu (Anadara inflata) mengandung protein $6,75-11,92 \%$, lemak 4,2-6,6\%, dan karbohidrat 2,3-4,32\% (Arnanda, Ambariyanto, \& Ridlo, 2005). Komposisi yang berbeda terdapat pada daging Anadara antiquata, yaitu protein $12,89 \%$, lemak 2,29\%, dan karbohidrat 3,56\%, sedangkan jeroan terdiri dari protein $10,13 \%$, lemak 4,60\%, dan karbohidrat $1,78 \%$ (Hidayat, 2011). Kedua bagian tubuh tersebut juga mengandung 9 asam amino esensial dan 6 asam amino non esensial. Penelitian lain menambahkan peningkatan variasi kerang akan meningkatkan diet yang sehat, karena kerang merupakan bahan makanan rendah lemak (lemak tersaturasi) berupa omega-3, sumber protein, $\mathrm{Fe}, \mathrm{Zn}, \mathrm{Cu}$, dan vitamin $\mathrm{B}-12$ (Dong, 2010).

Selama ini kerang banyak dianggap masyarakat umum sebagai makanan yang tergolong afrodisia, yaitu makanan yang mampu meningkatkan kemampuan seksual. Beberapa penelitian memang menunjukkan efek kerang terhadap faktor-faktor yang berhubungan dengan reproduksi. Manfaat $A$. granosa terhadap kesuburan pria adalah dapat memperbaiki volume, $\mathrm{pH}$, bau, dan warna semen. Kualitas spermatozoa juga mampu ditingkatkan setelah pemberian ramuan daging kerang A. granosa sebagai food supplement bahkan dosis $2 \times 1$ lebih baik dibanding $1 \times 1$ (Ferial \& Muchlis, 2013). Salah satu penelitian menerangkan, pemberian A. granosa berpengaruh terhadap tingkat kepadatan spermatozoa Mus musculus (Nirmalasari, 2017). Berdasarkan kandungan nutrisi khususnya protein, A. antiquata mempunyai komposisi lebih tinggi dibanding dengan $A$. granosa, sebaliknya, kajian $A$. antiquata terhadap kesuburan pria belum nampak. Oleh karena itu, potensi $A$. antiquata perlu dipertimbangkan dalam meningkatkan kualitas spermatozoa. Penelitian ini bertujuan untuk mengetahui efek kerang bulu (Anadara antiquata) terhadap kuantitas dan kualitas spermatozoa M. musculus. Hasil penelitian ini akan digunakan untuk konfirmasi bahwa mengkonsumsi $A$. antiquata bermanfaat untuk kesuburan pria seperti anggapan masyarakat selama ini.

\section{MATERIAL DAN METODE}

Penelitian ini merupakan eksperimen murni menggunakan rancangan acak lengkap (RAL) faktorial dengan 2 faktor. Faktor pertama adalah pemberian kerang dengan 2 tipe pengolahan, yaitu mentah dan dikukus. Faktor kedua adalah 3 taraf konsentrasi, yaitu $0 \%$ (kontrol), 75\%, dan 100\%. Penentuan konsentrasi dilakukan setelah mendapatkan hasil LD50. Hewan uji yang digunakan dalam penelitian ini adalah mencit (M. musculus) jantan berusia 4 minggu dan berat badan ratarata 10-11 gram, sehat, dan aktif sebanyak 25 ekor. Hewan uji ditempatkan di dalam kandang bak plastik berukuran $35 \mathrm{~cm}$ x $20 \mathrm{~cm}$ x $17 \mathrm{~cm}$ yang diberi alas serbuk kayu dan diberi tutup 
kawat. Setiap kandang berisi 5 ekor hewan dan ditempatkan pada tempat yang sama. Sebelum diberi perlakuan, hewan diaklimatisasi selama 1 minggu dengan tujuan agar dapat beradaptasi dengan lingkungan baru. Selama tahap aklimatisasi, M. musculus diberikan pakan standar (pelet) dan air secara ad libitum.

\section{Perlakuan}

Perlakuan yang dilakukan dalam penelitian ini adalah pemberian makan kerang bulu (A. antiquata) mentah dan dikukus masing-masing dosis $75 \mathrm{~g} / 100 \mathrm{~mL}$ dan 100 $\mathrm{g} / 100 \mathrm{~mL}$. Pengolahan dosis mentah dengan cara: A. antiquata segar dibersihkan, kemudian dipisahkan dari cangkangnya. Daging kerang dihaluskan, kemudian ditimbang sesuai dosis. Dosis $75 \%$ dibuat dengan cara $75 \mathrm{~g}$ daging dilarutkan dengan akuades hingga $100 \mathrm{~mL}$, kemudian disaring. Hal yang sama dilakukan untuk dosis 100\%, di mana daging yang digunakan 100 g. Pembuatan dosis kukus dilakukan dengan cara yang sama dengan dosis mentah, tetapi A. antiquata dikukus dahulu selama \pm 15 menit, setelah itu dagingnya dipisahkan dari cangkang dan dihaluskan. A. antiquata diberikan pada masing-masing mencit kelompok perlakuan selama 6 minggu secara oral menggunakan sonde sebanyak 1,5 $\mathrm{mL}$ pada waktu pagi, siang, dan sore, sementara untuk kontrol tidak diberikan $A$. antiquata.

\section{Pengamatan Spermatozoa M. musculus}

Setelah perlakuan, mencit dibunuh menggunakan metode dislokasi servical dan diambil bagian epididimisnya. Epididimis dipotong kecil-kecil menggunakan gunting kemudian diletakkan di cawan petri yang berisi $1 \mathrm{~mL} \mathrm{NaCl}$ fisiologis $0,9 \%$ dan diaduk dengan batang pengaduk hingga membentuk suspensi spermatozoa. Suspensi ini dibuat dari 5 kelompok perlakuan yang berbeda. Pengamatan spermatozoa yang meliputi konsentrasi, motilitas, dan morfologi spermatozoa menggunakan mikroskop multimedia. Konsentrasi spermatozoa dihitung menggunakan kamar hitung Neubauer. Satu tetes suspensi spermatozoa $(10 \mu \mathrm{L})$ diteteskan pada kamar hitung, lalu ditutup dengan cover glass. Setelah sediaan menyebar, pengamatan dilakukan dengan pembesaran 40 x 10 kali. Jumlah total spermatozoa (juta/mL) dihitung dari faktor pengenceran $\mathrm{x}$ jumlah hasil pengamatan $\mathrm{x} \quad 0,05 \quad \mathrm{x} \quad 10^{6}$. Motilitas spermatozoa diamati dengan cara $10 \mu \mathrm{L}$ suspensi spermatozoa diteteskan pada kaca benda, ditutupi dengan kaca penutup dan diamati dengan pembesaran 40 x 10 kali. Kategori gerakan yang diamati adalah: a) progessive, yaitu spermatozoa bergerak dengan aktif atau cepat baik linier atau dalam lingkaran besar, b) non-progessive, yaitu spermatozoa berenang di dalam lingkaran kecil, atau hanya flagel saja yang bergerak, dan c) immotility (IM), yaitu spermatozoa tidak bergerak. Motilitas spermatozoa dihitung dengan membagi jumlah spermatozoa kategori $a+b$ dengan kategori $a+b+c$ dikalikan $100 \%$. Sebelum mengamati morfologi spermatozoa, dibuat preparat apusan dengan cara meneteskan satu tetes suspensi spermatozoa pada kaca objek dan dibiarkan kering. Selanjutnya kaca objek direndam dalam metanol absolut 5 menit, dibilas dengan akuades dan dikeringkan. Perendaman berikutnya dalam larutan safranin 5 menit, 3 kali pencelupan dalam larutan buffer fosfat dan dalam larutan kristal violet selama 5 menit. Setelah dibilas dengan air mengalir dan kering, spermatozoa diamati di bawah mikroskop dengan pembesaran 1.000 kali dan diamati sebanyak 100 spermatozoa. Spermatozoa yang normal memiliki kepala yang menyerupai kait, meruncing, dan melengkung, tidak melingkar, serta ekor yang panjang dan lurus. Spermatozoa yang abnormal dinilai dari bentuk kepala, leher, dan ekor. Merujuk World Health Organization (2010), beberapa kelainan dari bentuk kepala adalah ganda, amorf, mikro, bulat, sedangkan ekor yang abnormal meliputi ekor yang pendek, ganda, patah, membentuk sudut, dan membentuk loop. Walaupun nampak kurang jelas, beberapa bentuk leher yang abnormal seperti asimetris, masuk ke kepala spermatozoa, tebal, dan bengkok yang tajam. Persentase jumlah spermatozoa normal dihitung dari pembagian spermatozoa bentuk normal dengan semua spermatozoa yang diamati dikalikan $100 \%$.

\section{Analisis Data}

Setelah diketahui kondisi data berdistribusi normal tetapi tidak homogen, data dianalisis statistik menggunakan uji Kruskal- 
Wallis untuk mengetahui apakah terdapat perbedaan oleh perlakuan. Uji lanjut untuk mengetahui perbedaan antar perlakuan digunakan uji Duncan.

HASIL

Hasil pengamatan konsentrasi spermatozoa sebagai respon dari pemberian $A$. antiquata disajikan pada Gambar 1. Kelompok kontrol mempunyai rata-rata konsentrasi spermatozoa terendah $(18,78$ juta/mL), sebaliknya perlakuan kerang yang dikukus dengan konsentrasi $75 \mathrm{~g} / 100 \mathrm{~mL}$ memiliki rata-rata konsentrasi tertinggi $(59,56 \mathrm{juta} / \mathrm{mL})$.

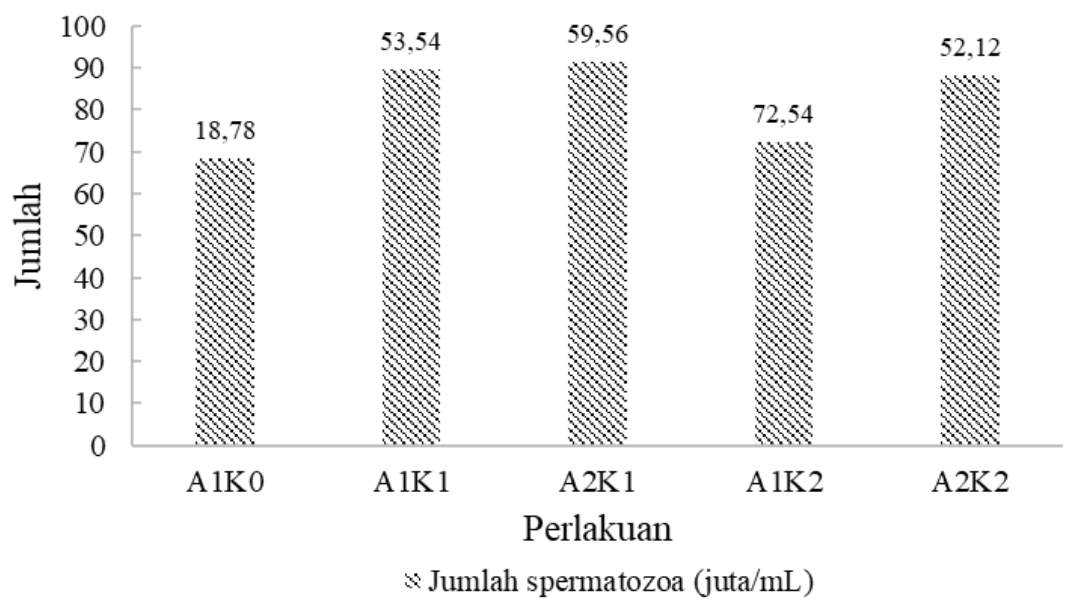

Gambar 1. Rata-rata konsentrasi spermatozoa (juta/mL) M. musculus setelah pemberian $A$. antiquata

Konfirmasi data konsentrasi spermatozoa ditunjukkan dari hasil analisis uji KruskalWallis, yaitu ada perbedaan antara perlakuan dan kontrol $(p<0,05)$. Selanjutnya hasil uji Duncan (Tabel 1) memperlihatkan bahwa hanya perlakuan kerang mentah dengan konsentrasi $100 \mathrm{~g} / 100 \mathrm{~mL}$ yang berbeda, sedangkan tiga perlakuan lainnya (mentah dengan konsentrasi $75 \mathrm{~g} / 100 \mathrm{~mL}$, kukus dengan konsentrasi $75 \mathrm{~g} / 100 \mathrm{~mL}$, dan 100 $\mathrm{g} / 100 \mathrm{~mL}$ ) tidak berbeda.

Kondisi yang sama juga nampak pada hasil pengamatan terhadap motilitas spermatozoa setelah diberikan A. antiquate. Gambar 2 menampilkan rata-rata motilitas spermatozoa kelompok kontrol paling rendah $(68,42 \%)$, sedangkan perlakuan kerang yang dikukus dengan konsentrasi $75 \mathrm{~g} / 100 \mathrm{~mL}$ mempunyai rata-rata tertinggi.

Demikian juga dengan hasil analisis uji Kruskal-Wallis yang menggambarkan hal yang sama dengan konsentrasi spermatozoa, yaitu ada perbedaan antara perlakuan dan kontrol $(p<0,05)$. Namun demikian, uji lanjut Duncan menunjukkan hal yang agak berbeda dengan konsentrasi spermatozoa, yaitu perlakuan kerang mentah dengan konsentrasi $75 \mathrm{~g} / 100$ $\mathrm{mL}$ tidak berbada dengan kerang kukus 75 $\mathrm{g} / 100 \mathrm{~mL}$ tetapi berbeda tidak signifikan dengan perlakuan kerang kukus konsentrasi $100 \mathrm{~g} / 100 \mathrm{~mL}$. Sementara itu, perlakuan kerang mentah konsentrasi $100 \mathrm{~g} / 100 \mathrm{~mL}$ berbeda tidak signifikan dengan perlakuan kukus $100 \mathrm{~g} / 100 \mathrm{~mL}$.

Hasil pengamatan rata-rata morfologi spermatozoa setelah pemberian $A$. antiquate sama dengan rata-rata konsentrasi dan motilitas, kelompok kontrol menunjukkan ratarata terendah, sedangkan perlakuan kerang kukus konsentrasi $75 \mathrm{~g} / 100 \mathrm{~mL}$ mempunyai rata-rata tertinggi (Gambar 3). Berbeda dengan dua parameter tersebut, hasil uji KruskalWallis tidak menunjukkan perbedaan $(p<0,05)$.

Meskipun data morfologi spermatozoa tidak menunjukkan perbedaan yang signifikan antar perlakuan, ditemukan beberapa morfologi spermatozoa abnormal seperti yang ditampilkan pada Gambar 4B dan C. Spermatozoa normal menampilkan kepala menyerupai kait meruncing dan melengkung, serta ekor panjang dan lurus. Morfologi spermatozoa yang tidak normal berupa bentuk mikro dan ekor membentuk loop seperti yang ditunjukkan tanda panah 1. Morfologi spermatozoa abnormal lainnya kepala bulat dan besar (tanda panah 2) dan ekor bergelombang atau bengkok (tanda panah 3 ). 


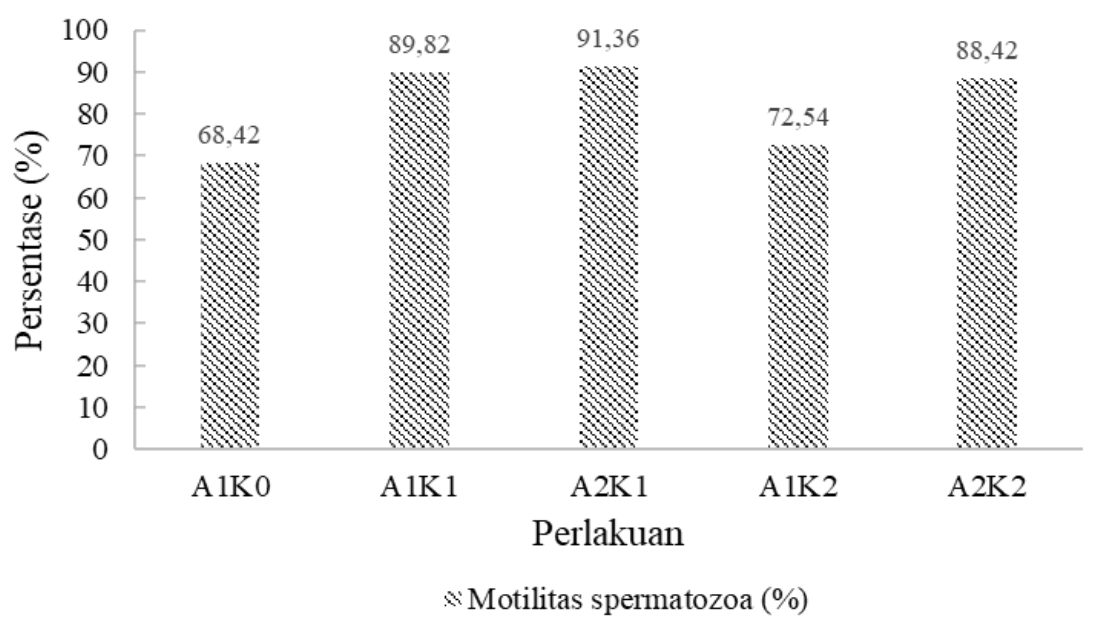

Gambar 2. Rata-rata motilitas spermatozoa (\%) M. musculus setelah pemberian A. antiquata

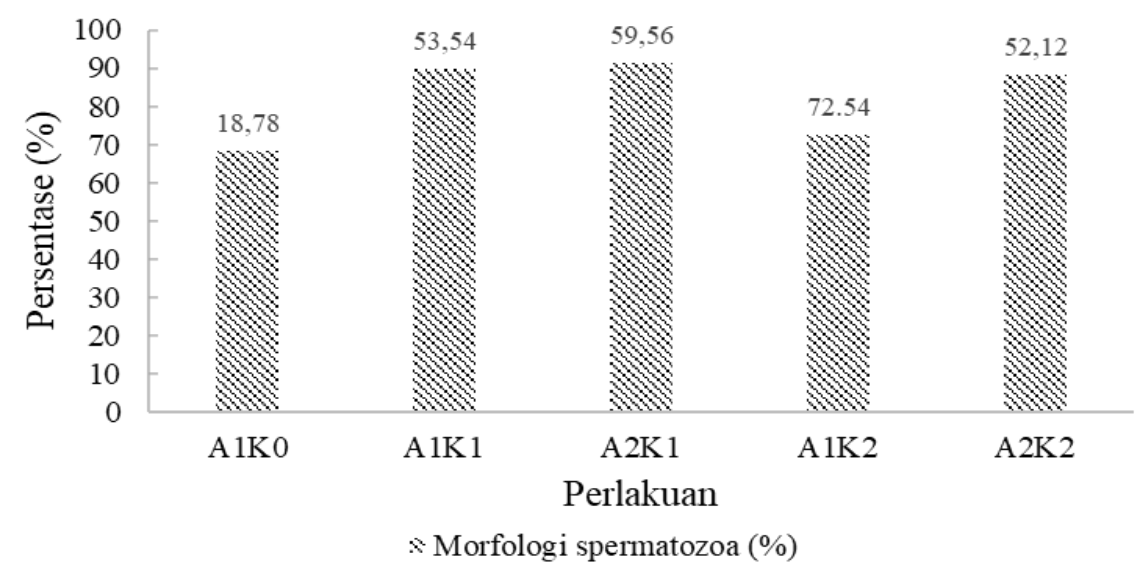

Gambar 3. Rata-rata morfologi spermatozoa normal (\%) M. musculus setelah pemberian A. antiquata

Hasil pengamatan rata-rata morfologi spermatozoa setelah pemberian A. antiquate sama dengan rata-rata konsentrasi dan motilitas, kelompok kontrol menunjukkan ratarata terendah, sedangkan perlakuan kerang kukus konsentrasi 75 g/100 mL mempunyai rata-rata tertinggi (Gambar 3). Berbeda dengan dua parameter tersebut, hasil uji KruskalWallis tidak menunjukkan perbedaan $(p<0,05)$.

Meskipun data morfologi spermatozoa tidak menunjukkan perbedaan yang signifikan antar perlakuan, ditemukan beberapa morfologi
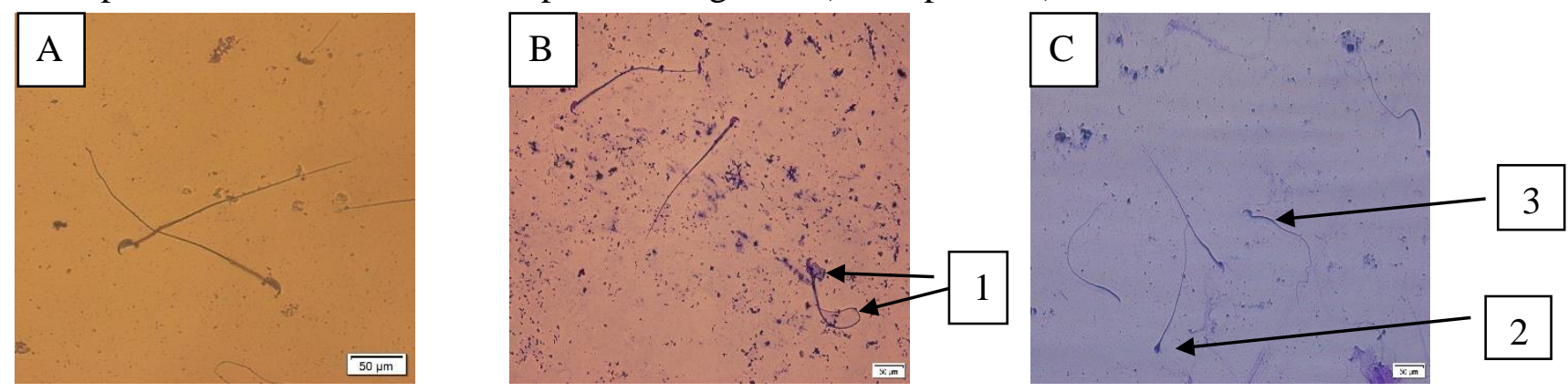

spermatozoa abnormal seperti yang ditampilkan pada Gambar 4B dan C. Spermatozoa normal menampilkan kepala menyerupai kait yang meruncing dan melengkung, serta ekor yang panjang dan lurus. Morfologi spermatozoa yang tidak normal berupa bentuk mikro dan ekor membentuk loop seperti yang ditunjukkan tanda panah 1. Morfologi spermatozoa abnormal lainnya kepala bulat dan besar (tanda panah 2) dan ekor bergelombang atau bengkok (tanda panah 3).

Gambar 4. Spermatozoa normal (A) dan abnormal (B dan C), diambil dengan perbesaran 400 kali, pewarnaan safranin dan kristal violet 
Tabel 1. Hasil uji lanjut duncan tentang perbedaan jumlah, motilitas dan morfologi spermatozoa antar perlakuan

\begin{tabular}{cccccc}
\hline Parameter & \multicolumn{5}{c}{ Perlakuan } \\
\cline { 2 - 6 } & $\mathrm{A}_{1} \mathrm{~K}_{0}$ & $\mathrm{~A}_{1} \mathrm{~K}_{1}$ & $\mathrm{~A}_{2} \mathrm{~K}_{1}$ & $\mathrm{~A}_{1} \mathrm{~K}_{2}$ & $\mathrm{~A}_{2} \mathrm{~K}_{2}$ \\
Jumlah spermatozoa & $18,78^{\mathrm{a}}$ & $53,54^{\mathrm{c}}$ & $59,56^{\mathrm{c}}$ & $34,00^{\mathrm{b}}$ & $52,12^{\mathrm{c}}$ \\
(juta/mL) & $\pm 1,846$ & $\pm 9,093$ & $\pm 17,431$ & $\pm 12,605$ & $\pm 4,435$ \\
& & & & \\
Motilitas spermatozoa & $68,42^{\mathrm{a}}$ & $89,82^{\mathrm{c}}$ & $91,36^{\mathrm{c}}$ & $72,54^{\mathrm{ab}}$ & $88,42^{\mathrm{bc}}$ \\
$(\%)$ & $\pm 10,833$ & $\pm 2,241$ & $\pm 2,419$ & $\pm 24,741$ & $\pm 1,464$ \\
& & & & \\
Morfologi spermatozoa & $85,40^{\mathrm{a}}$ & $89,40^{\mathrm{ab}}$ & $91,80^{\mathrm{b}}$ & $88,40^{\mathrm{ab}}$ & $89,60^{\mathrm{ab}}$ \\
$(\%)$ & $\pm 4,561$ & $\pm 5,459$ & $\pm 1,924$ & $\pm 4,278$ & $\pm 4,393$ \\
\hline
\end{tabular}

Keterangan:

abc = Huruf yang berbeda menunjukkan perbedaan yang nyata pada baris yang sama

$\mathrm{A} 1 \mathrm{~K} 0 \quad=$ Kontrol

A1K1 = Pemberian kerang mentah $75 \mathrm{~g} / 100 \mathrm{~mL}$ air,

$\mathrm{A} 2 \mathrm{~K} 1=$ Pemberian kerang kukus $75 \mathrm{~g} / 100 \mathrm{~mL}$ air,

A1K2 = Pemberian kerang mentah $100 \mathrm{~g} / 100 \mathrm{~mL}$ air

A2K2 $=$ Pemberian kerang kukus $100 \mathrm{~g} / 100 \mathrm{~mL}$ air

\section{PEMBAHASAN}

Hasil penelitian menunjukkan bahwa pemberian $A$. antiquata memengaruhi konsentrasi spermatozoa. Jumlah spermatozoa yang diejakulasikan dinilai dari konsentrasi spermatozoa, sekaligus mencerminkan fungsi testis sebagai organ yang memproduksi spermatozoa. Selanjutnya spermatozoa mengalami proses maturasi di epididimis hingga diekskresikan. Spermatogenesis meliputi tiga tahap utama, yaitu proriferasi spermatogonia, meiosis spermatosit, dan spermiogenesis (Haviz, 2013). Selain ditentukan oleh gen, proses tersebut dipengaruhi oleh berbagai interaksi hormon. Hormon yang terlibat merupakan produk dari hipotalamus dan hipofise, yaitu Gonadotropin-ReleasingHormone (GnRH) yang dikeluarkan oleh hipotalamus yang merangsang hipofise untuk mensekresikan Lutenizing Hormone (LH) dan Follicle Stimulating Hormone (FSH). Selanjutnya LH menyebabkan sel-sel leidig mengeluarkan testosteron, sementara FSH menstimulasi sel-sel sertoli untuk membebaskan Androgen Binding Protein (ABP). Kedua hormon ini berperan penting dalam proses pembentukan spermatozoa hingga menghasilkan spermatozoa dengan bentuk yang sempurna, yang disebut dengan spermatozoa yang matang (mature). Hormon testosteron mulai berperan setelah tahap spermatosit primer, sedangkan FSH berfungsi pada tahap spermatid akhir sampai terbentuknya spermatozoa yang lengkap. ABP memudahkan testosteron untuk ditransportasikan ke epididimis dan dikonversi menjadi Dihidrotestosterone (DHT) yang berperan dalam proses pematangan spermatozoa sehingga dapat bergerak secara aktif (Ramaswamy \& Weinbauer, 2014; Smith \& Walker, 2014).

Kerja hormon dalam spermatogenesis didukung oleh protein struktural spesifik protamine. Protein ini berperan selama fase spermiogenesis, dimana terjadi pemanjangan (elongation) dari spermatid yang berbentuk bundar (Ohta et al., 2007). Histon yang terdapat di dalam inti spermatozoa digantikan oleh protamine yang sangat penting untuk penyusunan kromatin dalam rangka pematangan spermatozoa (Arpanahi et al., 2009). Protein dikenal sebagai nutrisi yang berperan dalam pembentuk struktur, sehingga sangat dibutuhkan dalam proses proliferasi spermatogonia. Spermatogonia dibentuk secara mitosis, yang akan menghasilkan sel baru berupa spermatogonia bertipe A dan spermatogonia bertipe B. Selanjutnya spermatogonia tipe $\mathrm{B}$ mengalami pembelahan secara mitosis lagi membentuk dua sel yang disebut spermatosit primer (Hasbi \& Gustina, 2018).

Hormon dan protamine merupakan bahan yang disusun oleh protein sebagai bahan baku 
utama, sementara A. antiquata adalah bahan makanan yang dominan kandungan proteinnya, yaitu 6,75-11,92\% (Arnanda et al., 2005). Ditambahkan oleh Hidayat (2011), protein yang terkandung dalam $A$. antiquata adalah protein dengan sembilan asam amino esensial. Asam amino esensial adalah asam amino yang harus diperoleh dari luar tubuh dari bahan makanan yang mengandung protein hewani, karena asam amino jenis ini tidak dapat diproduksi oleh tubuh. Kebiasaan diet dengan seafood sangat bermanfaat untuk kesehatan (Dong, 2010). Hal ini didukung oleh Styne (2003) yang menunjukkan, bahwa nutrisi berperan dalam proses perubahan sekresi hormon. Rendahnya status nutrisi akan memperparah pertumbuhan pubertas, hingga menyebabkan sterilitas. Dengan demikian, kondisi inilah yang dapat menjelaskan tingginya konsentrasi spermatozoa pada kelompok perlakuan setelah pemberian A.antiquata dibanding dengan kontrol.

Selain protein, A. antiquata juga mengandung golongan kolesterol yang berfungsi sebagai bahan untuk sintesis testosteron. Sebagai pembanding, hasil penelitian (Hasyimi, Agustono, \& Paramitha, 2018) menunjukkan kandungan kolesterol dalam A. granosa 158,386-177,295 mg/100gr. Hormon ini berperan dalam proses pematangan spermatozoa. Seperti yang telah dijelaskan sebelumnya, lemak yang terdapat pada kerang ini merupakan lemak tersaturasi. Testosteron merupakan hormon androgen, untuk sintesis hormon golongan ini umumnya membutuhkan prekursor hormon berupa kolesterol.

Kandungan nutrisi yang juga sangat berperan dalam peningkatan konsentrasi spermatozoa adalah mineral. Nurnadia, Azrina, Amin, Yunus, dan Effendi (2013) melaporkan kandungan mineral $\mathrm{Zn}$ pada kerang merupakan yang terbanyak, yaitu $14671,24 \mathrm{mg} / 100 \mathrm{~g}$ berat basah. Salah satu mineral yang sudah terbukti bermanfaat terhadap kualitas spermatozoa adalah seng (Zn). Zn merupakan mineral yang diperlukan untuk mengaktivasi beberapa enzim. Hasil studi menunjukkan pemberian $\mathrm{Zn}$ efektif mempertahankan jumlah dan motilitas spermatozoa pada tikus setelah dipapar dengan bidang magnetik (Saki, Rahim, \& Dahaz, 2010). Dengan demikian, spermatozoa tetap mempunyai kapasitas untuk fertilisasi. Penelitian lain juga menegaskan bahwa ion $\mathrm{Zn}$ penting untuk fertilitas pria sehingga dapat meningkatkan kesehatan reproduksi pria (Kerns, Zigo, \& Sutovsky, 2018).

Proses pematangan spermatozoa terjadi di epididimis, yang calon spermatozoa akan mengalami perubahan morfologi. Di sini akan disekresi beberapa bahan yang penting untuk menunjang proses pematangan spermatozoa. Selama proses maturase, perubahan struktural terhadap morfologi terjadi di bagian kepala dan ekor spermatozoa, dan disertai dengan peningkatan motilitas spermatozoa progresif (Borg, Wolski, Gibbs, \& O’Bryan, 2009). Spermatozoa yang mature dinilai dari bagian kepala, badan, dan flagellum (ekor). Pada bagian kepala terdapat nukleus yang dilapisi akrosom mengandung enzim, dan diperlukan pada saat menembus ovum. Bagian badan spermatozoa mengandung mitokondria yang berfungsi memproduksi ATP untuk pergerakan bagian ekor. Gerakan ekor yang bergelombang mengakibatkan motilitas spermatozoa untuk berenang (Claudia, De Queljoe, \& Tendean, 2013). Kemudian tahap selanjutnya spermatozoa disimpan dalam kauda epididimis (Bertol et al., 2013).

Seperti halnya konsentrasi spermatozoa, pemberian $A$. antiquata juga menunjukkan pengaruh yang signifikan terhadap parameter motilitas spermatozoa. Motilitas yang diamati adalah motilitas normal dengan kategori bergerak maju lurus maupun tidak lurus. Data menunjukkan, adanya peningkatan spermatozoa dengan motilitas normal pada perlakuan dibandingkan kontrol. Selain didukung oleh struktur yang lengkap, motilitas spermatozoa ditentukan oleh adanya energi yang dihasilkan dari bagian pangkal ekor (midpiece). Persentase motilitas spermatozoa yang bergerak progressive dan nonprogressive pada kelompok perlakuan lebih tinggi dibanding dengan kontrol, yang berkaitan dengan kualitas struktur spermatozoa yang disebabkan oleh kandungan zat gizi seperti protein (asam amino), lemak, dan mineral pada A. antiquata. Protein merupakan substrat yang diperlukan dalam proses pematangan spermatozoa, karena pada proses tersebut terjadi perubahan struktural pada spermatozoa, sehingga akan berdampak pada peningkatan 
motilitas spermatozoa progressive (Borg et al., 2009).

Spermatozoa memerlukan energi untuk bergerak, yang berasal dari bagian ekor spermatozoa. Hal ini karena pada bagian ekor, tepatnya pada bagian pangkal, mengandung mitokondria yang berfungsi menghasilkan energi untuk metabolisme. Energi yang digunakan merupakan energi kimia yang berasal dari perombakan adenosine triphosphate (ATP) menjadi adenosine diphosphate (ADP) dan adenosine monophosphate (AMP). Energi ini kemudian disalurkan pada bagian distal (end piece) yang menyebabkan pergerakan spermatozoa (Tjipto, 2010). Dengan demikian, spermatozoa yang mempunyai morfologi normal akan mendukung gerak (motil) spermatozoa untuk masuk ke organ reproduksi betina.

Selain jumlah dan motilitas, morfologi spermatozoa juga dijadikan kriteria penilaian fertilitas individu jantan. Bentuk spermatozoa mencit yang normal, dilihat dari bentuk kepala yang mempunyai kait runcing dan ekor panjang lurus. Bentuk seperti kepala amorf (tidak berbentuk) atau bulat besar, dan ekor yang coil atau pendek adalah beberapa bentuk abnormal. Kondisi demikian menurut istilah World Health Organization (2010) disebut teratozoospermia. Abnormalitas spermatozoa dapat berupa abnormalitas primer dan abnormalitas sekunder. Abnormalitas primer terjadi karena kelainan pada saat spermatogenesis di dalam tubulus seminiferus, sedangkan abnormalitas sekunder terjadi setelah spermatozoa meninggalkan tubulus seminiferous, dan selama perjalanan melalui epididimis. Keadaan morfologi spermatozoa yang mengalami kelainan (abnormal) juga dapat memicu gerakan spermatozoa menjadi terganggu. Spermatozoa yang normal akan bergerak progresif, yaitu gerakan yang aktif maju ke depan (Laili, 2017).

Berbeda dengan dua parameter tersebut, pemberian $A$. antiquata tidak memberikan pengaruh yang signifikan terhadap morfologi normal spermatozoa. Kondisi ini sangat mendukung dua parameter spermatozoa, yaitu jumlah dan motilitas. Hal tersebut berarti nutrisi yang terkandung dalam A. Antiquata, terutama protein, tidak hanya berperan dalam meningkatkan jumlah spermatozoa, tetapi juga struktur atau morfologi spermatozoa yang normal. Hasil penelitian ini sesuai dengan penelitian lain bahwa zat gizi yang ada pada kerang, mampu memberikan efek atau perbaikan pada morfologi spermatozoa. Protein disekresi dari epididimis berperan dalam proses pematangan spermatozoa, dalam hal ini spermatozoa mengalami perubahanperubahan struktur, baik di bagian kepala maupun ekor (Bertol et al., 2013). Oleh karena itu, spermatozoa normal mempunyai efek motilitas yang normal pula. Secara umum hasil penelitian ini mengonfirmasikan bahwa efek nutrisi tidak selalu menyebabkan peningkatan semua parameter spermatozoa.

Berdasarkan dosis yang diberikan, perlakuan antara kerang mentah dan kukus sama-sama memberikan pengaruh terhadap peningkatan konsentrasi dan motilitas spermatozoa, tetapi tidak untuk morfologi. Namun demikian, data rata-rata dari ketiga parameter menunjukkan perlakuan dikukus 75 $\mathrm{g} / 100 \mathrm{~mL}$ merupakan jumlah tertinggi, sedangkan yang mentah $100 \mathrm{~g} / 100 \mathrm{~mL}$ mempunyai jumlah terendah. Berdasarkan data ini, nampak bahwa perlakuan dikukus dan mentah merupakan faktor yang lebih menentukan dibanding dosis. Hal ini dapat dilihat dari perbedaan yang signifikan di antara perlakuan mentah dan kukus untuk dosis yang sama $100 \mathrm{~g} / 100 \mathrm{~mL}$ dan $75 \mathrm{~g} / 100 \mathrm{~mL}$. Sementara itu, dosis $75 \mathrm{~g} / \mathrm{mL}$ dan 100 $\mathrm{g} / 100 \mathrm{~mL}$ pada kondisi mentah dan kukus tidak menunjukkan perbedaan.

Perlakuan pemasakan akan memengaruhi nutrisi yang terdapat dalam bahan makanan. Hal ini didukung oleh penelitian Ifemeje et al. (2015) yang melaporkan terjadi penurunan signifikan kandungan protein, lemak (crude), total karbohidrat, dan mineral $\mathrm{Fe}, \mathrm{Zn}$, serta $\mathrm{Ca}$, setelah pendidihan pada suhu $120{ }^{\circ} \mathrm{C}$ selama 15 menit. Hasil berbeda dilaporkan Joyce et al. (2016), bahwa peningkatan mineral $\mathrm{Fe}, \mathrm{Pb}$, dan $\mathrm{Cu}$, serta penurunan $\mathrm{Mn}$ dan $\mathrm{Zn}$ setelah pendidihan, sedangkan $\mathrm{Cd}$ tidak terpengaruh, tetapi tidak dijelaskan berapa suhu pendidihan. Berdasarkan hal ini, seharusnya parameter spermatozoa dari kerang mentah lebih tinggi dibandingkan dengan yang dikukus, tetapi efek yang nampak terhadap spermatozoa berbanding sebaliknya, meskipun kandungan nutrisi $A$. antiquate dalam penelitian ini belum 
dapat dipastikan, sehingga perlu penelitian lebih lanjut.

Kerang mentah dengan dosis $100 \mathrm{~g} / 100$ $\mathrm{mL}$ memberikan jumlah spermatozoa yang terendah, sedangkan kerang yang dikukus menyebabkan jumlah spermatozoa yang tertinggi. Namun demikian, kandungan nutrisi A. antiquate dalam penelitian ini belum dapat dipastikan sehingga perlu penelitian lanjutan. Kerang mentah berpotensi mengandung kandungan logam berbahaya seperti Timbal $(\mathrm{Pb})$, dan Cadmium $(\mathrm{Cd})$ dari habitatnya yang berada di perairan lumpur pasir dan cara mendapatkan makanan dengan cara menyaring partikel makanan, tidak terkecuali partikelpartikel yang mengandung logam. Timbal akan menurunkan kerja dari reseptor manosa, sehingga tidak mampu melakukan reaksi akrosom atau menyebabkan reaksi akrosom yang prematur. Keberadaan $\mathrm{Pb}$ membuat kompetisi dengan $\mathrm{Zn}$ dalam mengikat protamine, akibatnya stabilitas kromatin terganggu dan efek akhirnya akan menyebabkan fertilitas pada pria (Panggabean, Soeng, \& Ivone, 2008).

Salah satu penelitian menerangkan efek logam berbahaya $\mathrm{Cd}$ dan diazinon dosis rendah akan memengaruhi kualitas spermatozoa, yaitu mengganggu perubahan morfologi spermatozoa, sehingga memberikan efek pada motilitasnya dan menurunkan fertilitas pria (Adamkovicova et al., 2016). Salah satu hasil penelitian tentang bagaimana tercemarnya perairan oleh logam berbahaya dapat dirujuk dari data penelitian Melisa, Basyuni, dan Budiyulianto (2010), Pb yang terdapat dalam daging A. antiquata dari perairan Belawan adalah 3,6-5,6 mg/kg, sedangkan $\mathrm{Cd} \mathrm{1,5-1,6}$ $\mathrm{mg} / \mathrm{kg}$. Kandungan logam tersebut sudah melampaui batas dosis standar yang diijinkan dari batas maksimum cemaran logam berat dalam pangan (Standar Nasional Indonesia, 2009), yaitu $1,5 \mathrm{mg} / \mathrm{kg}$ untuk $\mathrm{Pb}$ dan 1,0 $\mathrm{mg} / \mathrm{kg}$ untuk $\mathrm{Cd}$. Hal ini menyebabkan akumulasi $\mathrm{Pb}$ dalam hewan perairan digunakan sebagai bioindikator untuk memonitoring adanya logam berbahaya sebagai polutan di air (Cruz, Vera, Lapie, Catalma, \& Bunal, 2017).

Kondisi yang menarik adalah perlakuan dosis $75 \mathrm{~g} / 100 \mathrm{~mL}$ justru menghasilkan parameter spermatozoa yang lebih baik dibandingkan dengan dosis $100 \mathrm{~g} / 100 \mathrm{~mL}$. Hal ini mengindikasikan peningkatan dosis memberikan efek buruk pada jumlah spermatozoa. Hasil penelitian ini searah dengan penggunaan dosis 3:1, yaitu juga menunjukkan semakin tinggi konsentrasi, ternyata jumlah spermatozoa mengalami penurunan (Nirmalasari, 2017). Penambahan dosis terbukti tidak linier dengan peningkatan jumlah spermatozoa, karena kelebihan maupun kekurangan konsumsi zat gizi dapat menurunkan kesehatan reproduksi, yang akan berdampak terhadap kuantitas dan kualitas spermatozoa (Ferial \& Muchlis, 2013).

\section{SIMPULAN DAN SARAN}

Konsumsi kerang bulu (Anadara antiquata) yang dikukus oleh Mus musculus L. memberikan efek yang lebih baik terhadap kuantitas dan kualitas spermatozoa dibandingkan dalam kondisi mentah. Peningkatan dosis perlakuan tidak menunjukkan linieritas terhadap respon spermatozoa. Penelitian selanjutnya sebaiknya dilakukan untuk ekstrak daging atau jeroan dari A.antiquata agar lebih memperjelas pengaruhnya terhadap kualitas spermatozoa.

\section{UCAPAN TERIMA KASIH}

Peneliti mengucapkan terima kasih atas dibiayainya sebagian penelitian ini oleh Hibah Penelitian Dasar Unggulan Perguruan Tinggi Tahun 2018.

\section{REFERENSI}

Adamkovicova, M., Toman, R., Martiniakova, M., Omelka, R., Babosova, R., Krajcovicova, V., ... Massanyi, P. (2016). Sperm motility and morphology changes in rats exposed to cadmium and diazinon.
Reproductive
Biology
and
Endocrinology, 14(1), 1-7. doi: 10.1186/s 12958-016-0177-6

Arnanda, A. D., Ambariyanto., \& Ridlo, A. (2005). Fluktuasi kandungan proksimat kerang bulu (Anadara inflata Reeve) di perairan pantai Semarang. Ilmu Kelautan, 10(2), 78-84. doi: 10.14710/ik.ijms.10.2.78-84

Arpanahi, A., Brinkworth, M., Iles, D., Krawetz, S. A., Paradowska, A., Platts, A. E., ... Miller, D. (2009). Endonuclease-sensitive regions of human spermatozoal chromatin are highly 
enriched in promoter and CTCF binding sequences. Genome Research, 19(8), 1338-1349. doi: 10.1101/gr.094953.109

Bertol, M. A., Weiss, R. R., Soccol, T. V., Kozicki, E. L., Fujita, S. A., Abreu, A. R., \& Green, T. K. (2013). Viability of bull spermatozoa epididymis stored at 18-20 ${ }^{\circ} \mathrm{C}$ collected from the epididymis stored at $18-20{ }^{\circ} \mathrm{C}$. Brazilian Archives of Biology and Technology, 56(5), 777-783. doi: 10.1590/S1516-89132013000500008

Borg, C. L., Wolski, K. M., Gibbs, G. M., \& O’Bryan, M. K. (2009). Phenotyping male infertility in the mouse: how to get the most out of a "non-performer. "Human Reproduction Update, 16(2), 205-224. doi: 10.1093/humupd/dmp032

Claudia, V., De Queljoe, E., \& Tendean, L. (2013). Perbedaan kualitas spermatozoa mencit jantan (Mus musculus L.) yang diberikan vitamin $\mathrm{C}$ setelah pemaparan asap rokok. Jurnal E-Biomedik, 1(1), 629-634.

doi:

10.35790/ebm.1.1.2013.4610

Cruz, C. P. P., Vera, D. N. M., Lapie, L. P., Catalma, M. N. A., \& Bunal, R. V. (2017). Bioaccumulation and health risks assessment of lead $(\mathrm{Pb})$ in freshwater asian $(\mathrm{Pb})$ in freshwater asian clams (Corbicula fluminea, Muller). Pollution Research, 36(2), 366-372.

Daluningrum, I. P. W. (2009). Penapisan awal komponen bioaktif dari kerang darah (Anadara granosa) sebagai senyawa antibakteri (Skripsi). Program Studi Teknologi Hasil Perikanan, Fakultas Perikanan dan Ilmu Kelautan, Institut Pertanian Bogor, Indonesia.

Dong, F. (2010). The nutritional value of shellfish. Washington: A Washington Sea Grant publication.

Ferial, E. W., \& Suryani, A. E. S. (2011). Kajian klinik pemberian gizi kerang darah Anadara granosa L. terhadap kualitas spermatozoid manusia. Jurnal Media Kesehatan Masyarakat Indonesia, 6(2), 120-126.

Ferial, E. W., \& Muchlis, A. (2013). Kajian pemeriksaan makroskopik spermatozoa manusia macroscopic examination of human spermatozoa through nutrition of blood cockle's (Anadara granosa L.).
Sainsmat: Jurnal Ilmiah Ilmu

Pengetahuan, 2(1), 1-13.

Hanizar, E. (2004). Delesi region AZF (azoospermic factor) dalam kromosom Y pria infertil berdasarkan etnis di Indonesia (Disertasi). Universitas Airlangga, Surabaya, Indonesia.

Hasbi, H., \& Gustina, S. (2018). Regulasi androgen dalam spermatogenesis untuk meningkatkan fertilitas ternak jantan. Wartazoa: Indonesian Bulletin of Animal and Veterinary Sciences, 28(1), 13-22.

Hasyimi, R., Agustono., \& Paramitha, W. (2018). Kandungan kolesterol pada kerang darah (Anadara granosa) dari hasil tangkap di Kenjeran Surabaya, Sedati Sidoarjo, dan Bancaran Bangkalan. Journal of Marine and Coastal Science, 7(1), 12-20.

Haviz, M. (2013). Dua sistem tubuh: reproduksi dan endokrin. Sainstek: Jurnal Sains dan Teknologi, 5(2), 153168.

Hidayat, T. (2011). Profil asam amino kerang bulu (Anadara antiquata) (Skripsi). Departemen Teknologi Hasil Perairan, Fakultas Perikanan dan Ilmu Kelautan, Institut Pertanian Bogor, Indonesia.

Hochschild, F. Z. E. (2009). The international committee for monitoring assisted reproductive technology (ICMART) and the World Health Organization (WHO) revised glossary on ART terminology. Human Reproduction, 24(11), 26862687. doi: 10.1093/humrep/dep343

Hopps, C. V., Mielnik, A., Goldstein, M., Palermo, G. D., Rosenwaks, Z., \& Schlegel, P. N. (2003). Detection of sperm in men with $\mathrm{Y}$ chromosome microdeletions of the AZFa, AZFb, and AZFc regions. Human Reproduction, 18(8), 1660-1665. doi: 10.1093/humrep/deg348

Hosomi, R., Yoshida, M., \& Fukunaga, K. (2012). Seafood consumption and components for health. Global Journal of Health Science, 4(3), 72-86. doi: 10.5539/gjhs.v4n3p72

Ifemeje, J., Udedi, S., Lukong, C., Nwaka, A., Egbuna, C., Okechukwu, A., \& Onwudiwe, F. (2015). Influence of heat processing on nutrient composition and 
energy values of selected cereals consumed in Nigeria. International Journal of Biochemistry Research \& Review, 7(1), 20-26. doi: 10.9734/ijbcrr/2015/12859

Joyce, K., Emikpe, B. O., Asare, D. A., Asenso, T. N., Yeboah, R., Jarikre, T. A., \& Jagun, J. A. (2016). Effects of different cooking methods on heavy metals level in fresh and smoked game meat. Journal of Food Processing \& Technology, 7(9), 9-11. doi: 10.4172/2157-7110.1000617

Kerns, K., Zigo, M., \& Sutovsky, P. (2018). Zinc: a necessary ion for mammalian sperm fertilization competency. International Journal of Molecular Sciences, 19(12). doi: 10.3390/ijms19124097

Laili, N. (2017). Penurunan motilitas spermatozoa tikus putih (Rattus norvegicus) jantan akibat pemberian infusa buah Adas (Foeniculum vulgare Mill). Jurnal Kesehatan Bakti Tunas Husada, 17(2), 536-540.

Melisa, R., Basyuni, M., \& Budiyulianto, E. (2010). Analisis kandungan kadmium (Cd) dan timbal $(\mathrm{Pb})$ pada air, sedimen dan kerang bulu (Anadara antiquata) di perairan pesisir Belawan provinsi Sumatera Utara (Tesis master). Program Studi Manajemen Sumberdaya Perairan, Fakultas Pertanian. Universitas Sumatera Utara, Indonesia.

Nirmalasari, R. (2017). Pengaruh pemberian nutrisi kerang darah Anadara granosa L. terhadap tingkat kepadatan spermatozoa mencit Mus musculus L. BIOMA: Jurnal Biologi Makassar, 2(1), 9-14. doi: 10.1017/CBO9781107415324.004

Nurnadia, A. A., Azrina, A., Amin, I., Yunus, Y. A. S., \& Effendi, M. I. H. (2013). Mineral contents of selected marine fish and shellfish from the west coast of Peninsular Malaysia. International Food Research Journal, 20(1), 431-437.
Ohta, T., Miyake, H., Miura, C., Kamei, H., Aida, K., \& Miura, T. (2007). Folliclestimulating hormone induces spermatogenesis mediated by androgen production in Japanese eel, Anguilla japonica L. Biology of Reproduction, 77(6), 970-977. doi: 10.1095/biolreprod.107.062299

Panggabean, P. T., Soeng, S., \& Ivone, J. (2008). Efek pajanan timbal terhadap infertilitas pria. Jurnal Kedokteran Maranatha, 8(1), 87-93.

Ramaswamy, S., \& Weinbauer, G. F. (2014). Endocrine control of spermatogenesis: role of FSH and LH/Testosterone. Spermatogenesis, 4(2), e996025. doi: 10.1080/21565562.2014.996025

Saki, G., Rahim, F., \& Dahaz, S. (2010). Effect of supplementation of zinc on count, motility and in vitro fertilization capacity of spermatozoa of magnetic field exposed rats. Journal of Biological Sciences, 10(2), 174-177.

Smith, L. B., \& Walker, W. H. (2014). The regulation of spermatogenesis by androgens. Seminars in Cell and Developmental Biology, 30, 2-13. doi: 10.1016/j.semcdb.2014.02.012

Standar Nasional Indonesia. (2009). Batas maksimum cemaran logam berat dalam pangan. Jakarta: Badan Standarisasi Indonesia.

Styne, D. M. (2003). The regulation of pubertal growth. Hormone Research, 60(1), 22-26. doi: 10.1159/000071222

Tjipto, B. W. (2010). Kajian infertil pria di laboratorium infertil-Andrologi PUSLITBANG sistem dan kebijakan kesehatan Surabaya. Buletin Penelitian Sistem Kesehatan, 13(2), 181-188.

World Health Organization. (2010). Laboratory manual for examination and processing of human semen $5^{\text {th }}$ edition. Switzerland: WHO Press. 